\title{
Konstruowanie „małżeńskiego ja”. Rodzina jako przestrzeń wsparcia i uczenia się partnerstwa małżonków
}

\author{
Constructing of „marital I”. A family as a space of spouses’ \\ support and learning equality
}

Streszczenie. Celem artykułu jest analiza funkcjonowania współczesnej rodziny jako przestrzeni budowania partnerstwa między małżonkami, którego podstawą jest wzajemne wspieranie się kobiet i mężczyzn w realizowaniu wielu ról równocześnie. Rekonstruuję w nim również potrzeby wsparcia, jakie ujawniają przepracowane rodziny, w dużej mierze wynikające z funkcjonującego w naszej kulturze mitu „normalnej” rodziny, utożsamianej z rodziną stereotypowych ról kobiet i mężczyzn, a których zaspokojenie ułatwiłoby małżonkom budowania partnerstwa. Proces ten traktuję jako aktywne konstruowanie przez małżonków „małżeńskiego ja" - części tożsamości w zbiorowej postaci (Kaufmann, 2004). W analizach odwołuję się do koncepcji: J. C. Kaufmanna (2004), „fuzji biografii” P. Bergera i H. Kellner (1964) oraz biograficznego uczenia się dorosłych w ujęciu P. Alheita (2002).

Słowa kluczowe: małżeństwo, rodzina partnerska, wsparcie, równość kobiet i mężczyzn, uczenie się dorosłych

Summary. The aim of the article is to analyze the functioning of a contemporary family as a space for building equality between spouses, based on the mutual support of women and men in carrying out many roles at the same time. I also reconstruct the needs of the support that families overloaded with work disclose, largely as a result of a myth of a "normal" family still strong in our culture, identified as a family of stereotypical roles for women and men. Meeting those needs would facilitate the building of spouses equality. I regard this process as active constructing of "marital I" by the spouses - part of the identity in a collective form (Kaufmann, 2004). In my analysis, I refer to the concepts of: J. C. Kaufmann (2004), P. Berger and H. Kellner's "biographical fusion" (1964) and biographical learning of adults by P. Alheit (2002).

Keywords: marriage, egalitarian family, support, equality of women and men, learning of adults 


\section{Wprowadzenie}

Współczesnie obserwujemy przemiany systemu ról płciowych oraz środowiska rodzinnego, które dokonują się na wielu poziomach, również w obszarze relacji wewnątrzrodzinnych. Zmiany te jedni uważają za przejawy kryzysu rodziny czy też jej upadku jako efektu rosnącej autonomii członków rodziny, a także wzrostu postaw i wartości indywidualistycznych, inni - za niezbędny proces jej transformacji w kierunku wyższej jakości życia małżonków i dzieci oraz ich wzajemnych relacji, opartych na bliskości i współpracy, co Anthony Giddens (1998, s. 144) nazywa tryumfem „emocjonalnego indywidualizmu” jako zasady kierującej życiem osobistym współczesnego człowieka.

Proces zmian postępuje w kierunku zmniejszania nierówności kobiet i mężczyzn w rodzinie (Slany, 2002). W ich obliczu, kobiety i mężczyźni zmuszeni są wypracowywać własne strategie budowania równości w relacjach wewnątrzrodzinnych. Owy przymus wynika często z konieczności (z)mierzenia się z dorobkiem własnej, indywidualnej przeszłości i efektami mniej lub bardziej stereotypowej socjalizacji rodzajowej, a także z dorobkiem kultury, historii oraz tradycji i religii, które jasno definiują kształt i zakres ról kobiet i mężczyzn, sytuując je w kontekście dorobku poprzednich pokoleń; wynika także z konieczności (z)mierzenia się z nową, nieznaną, rzadko doświadczaną w rodzinach pochodzenia codziennością związku opartego na partnerstwie, uwikłaną w szeroki kontekst przełomu ustrojowego, kulturowego i gospodarczego w Polsce - czasu „braku reguł” (Domański, Firkowska-Mankiewicz, Janicka, Titkow, 1993), wyznaczanego wymogami zmiennego i często sprzecznego z koncepcją życia w rodzinie rynku pracy.

Wspomniane przemiany ujawniają nowe problemy społeczne i ekonomiczne, które mają swoją specyfikę płciową. W przypadku kobiet pojawia się większe niż w przypadku mężczyzn narażenie na zubożenie, bezrobocie, dyskryminację i wykluczenie - zwłaszcza kobiet starszych, rozwiedzionych i/czy samotnie wychowujących dzieci (w literaturze pojawia się np. określenie „feminizacja biedy”). Z drugiej strony, kobiety podejmując zadania wynikające z nowych ról (zawodowych, publicznych), jednocześnie nie mając komu powierzyć tych dotychczas wykonywanych (domowych), częściej niż mężczyźni stają przed koniecznością godzenia wielu ról, przeciążenia spowodowanego tym procesem, konfliktem ról i w obrębie roli, co pokazuje w swoich badaniach np. Teresa Rostowska (2008; 2009).

Zmieniające się realia życia widoczne są również w funkcjonowaniu mężczyzn, równolegle ponoszących koszty za zmiany w systemie ról płciowych, choć w nieco innym wymiarze. Wyniki badań pokazują, że współcześ- 
ni mężczyźni mają problemy z poczuciem własnej wartości, popadają w nałogi, wzrasta poziom ich frustracji i agresji, w relacjach rodzinnych pojawia się więcej przemocy jako reakcji na poczucie „nieadekwatności” czy „niepasowania" do kulturowo ukształtowanej roli męża/ojca/głowy rodziny, co w literaturze bywa określane syndromem "nieadekwatnego męża” (inadequate husband syndrome) (Balswick, Balswick, 1995). O problemach z adaptacją i funkcjonowaniem społecznym części mężczyzn mogą również świadczyć wysokie wskaźniki bezrobocia, spadek wyników szkolnych chłopców, narastająca fala przemocy oraz wczesnej śmiertelności i samobójstw wśród mężczyzn (Dench, 1998; Pankowska, 2005). Odwołując się do szerokiego kontekstu socjokulturowego, do sposobów definiowania tego, czym jest rodzina i wewnątrzrodzinne relacje, a także stereotypowego postrzegania funkcjonowania współczesnych kobiet i mężczyzn, można stwierdzić, iż źródeł powyższych problemów można poszukiwać, oprócz w roli czynników osobowościowych i środowiskowych (Rostowski, 1987), również we wciąż żywym w naszej kulturze swoistym micie rodziny (Giza-Poleszczuk, 2005).

\section{Mit (normalnej) rodziny i jego konsekwencje}

Mit „normalnej”, często określanej tradycyjną lub świętą, jak zauważa Tomasz Szlendak (2010), pojawił się w naukach społecznych wraz z definicją rodziny nuklearnej z połączenia instytucjonalnego i religijnego wzorca życia rodzinnego. W efekcie tego połączenia zaczęły pojawiać się codzienne praktyki życia rodzinnego zgodne z tym wzorcem, a oparte na kulturowo ustalonych regułach i tradycyjnych rolach. Zgodnie z tym mitem, rodzina i jej trwanie są najważniejsze, jej członkowie powinni wyrzec się dobra indywidualnego, przyjąć każdy rodzaj krzywdy i nie powinni nigdy narzekać. Zgodnie $z$ uniwersalną funkcją mitu, służy on petryfikacji określonego - w tym wypadku „tradycyjnego" - wzorca rodziny, a także podtrzymaniu trwałości i niezmienności życia rodzinnego (Giza-Poleszczuk, 2005; Szlendak, 2010), co w czasach „płynnej rzeczywistości” (Bauman, 2007) i „permanentnej zmiany" (Sztompka, 2000) jest trudne do pogodzenia. A. Giza-Poleszczuk (2005) twierdzi, że normatywno-emocjonalne opisy rodziny, które dominują w literaturze, są idealne, najczęściej nie mające żadnego odzwierciedlenia w rzeczywistości. Ten konstrukt „normalnej” rodziny jest bowiem jedynie wymogiem funkcjonalnym. Zdaniem badaczy problematyki rodziny, zbytnie przywiązanie do jednostronnych wzorców rodziny stanowi źródło przemocy wobec niej na poziomie symbolicznym. Ta przemoc ma swe oblicze również 
w wymiarze jednostkowym, w sytuacji, gdy ludzie nie mogą sprostać wzorcowi mitu tradycyjnej rodziny, co skutkuje depresjami, poczuciem bycia gorszymi i narażeniem na społeczną kategoryzację przynależenia do „nie-normalnej" rodziny w odniesieniu do jej kulturowych sposobów definiowania. Rodzina więc, czy tego chce czy nie, aby nie zostać odrzuconą czy napiętnowaną, musi żyć zgodnie ze wzorcem mitu tradycyjnej rodziny (Giza-Poleszczuk, 2005; Szlendak, 2010).

Ten mit widoczny jest bardzo wyraźnie w polskiej pedagogice, w której dominuje, jak go określiła Mirosława Nowak-Dziemianowicz (2002), normatywno-ideologiczny dyskurs wiedzy o rodzinie. Ujawniają się w nim wartościowanie zamiast opisu, jasno określone cele - trwanie, a także funkcje, modele i postawy wychowawcze. Barbara Smolińska-Theiss o pedagogicznym dyskursie rodziny pisze, iż odwołuje się on „z jednej strony do raportów społecznych, a z drugiej strony do nauki społecznej Kościoła" (Smolińska-Theiss, 2014, s. 184), gdzie w różnych perspektywach, pisze dalej autorka, „miesza się akademicki opis z religijnym wartościowaniem i powinnością" (Ibidem). Każde odstępstwo i zmiana w obszarze życia rodzinnego rozważane są głównie w kategorii dysfunkcji, kryzysów i patologii. W dyskursie tym preferowany jest model rodziny tradycyjnej, w której panują hierarchiczne układy oparte na płci i wieku, a komplementarne wobec siebie role są przypisane ze względu na płeć. W tych uproszczonym, uniwersalnym obrazie, czy też micie rodziny, unika się, zdaniem B. Smolińskiej-Teiss, „podstawowych, kontrowersyjnych pytań o rolę i miejsce rodziny w socjalizacji dzieci, o przemiany współczesnej rodziny, teorie i język pozwalający opisywać te zmiany" (Ibidem). Gdyby wziąć pod uwagę kontekst zmiany społecznej, to oprócz pedagogicznych analiz rodzin narażonych na wykluczenie, biedę, marginalizację, należałoby także uważnie przyjrzeć się tym rodzinom, które również ponoszą konsekwencje tej zmiany, ale w innym wymiarze; rodzin nie będących podmiotem oddziaływań polityki socjalnej państwa. Jednym z typów takich rodzin może być rodzina partnerska, w dyskursie rodzinnym nazywana również egalitarną czy demokratyczną (Giddens, 1999; Dąbrowska, 2002; Ostrouch-Kamińska, 2011; Duch-Krzysztoszek, 2007).

Typ rodziny partnerskiej pojawia się w efekcie zmian cywilizacyjnych (Tyszka, 2002), które dotyczą prawie wszystkich obszarów życia społecznego. Jak pokazuje Piotr Sztompka (2004), w obliczu tych zmian, kiedy zajmowane pozycje stały się konsekwencją ich osiągania, a nie przypisania, jasno określone koncepcje ról kobiet i mężczyzn w rodzinie oraz ich uprawnienia i obowiązki, mające swe źródła w micie rodziny oraz tradycyjnej rodzinie patriarchalnej musiały przejść ewolucję. Jak pokazują wyniki badań 
przytoczonych poniżej, podstawowym warunkiem procesu negocjowania i konstruowania nowych/innych koncepcji ról rodzinnych jest zarówno wzajemne wsparcie okazywane sobie przez małżonków w obrębie rodziny, jak i wsparcie zewnętrzne: instytucjonalne oraz to związane ze społeczną świadomością partnerstwa kobiet i mężczyzn.

\section{Wsparcie jako podstawa funkcjonowania rodziny partnerskiej}

Wzajemne wsparcie małżonków jest jednym z podstawowych czynników decydujących o wysokiej jakości związku małżeńskiego, a w rodzinach, w których małżonkowie wykraczają poza stereotypowe role, w stronę większej równości - wydaje się być najważniejszym (Mandal, 2008). Z badań nad partnerstwem w rodzinach wynika, iż istnienie tego fenomenu możliwe jest dzięki wzajemnemu wsparciu okazywanemu sobie przez żony i mężów (Ostrouch-Kamińska, 2011). Wśród ujawnionych w badaniach strategii wsparcia, obok „wzajemnego zainteresowania i uwagi” oraz „otwartej komunikacji”, znalazły się także strategie „akceptacji”, jako dopełnienie triady strategii emocjonalnego wsparcia, oraz „braku sprzeciwu” wobec rozwoju i zaangażowania współmałżonka/-i w pracę zawodową, a także „udzielania czasu”. Ta ostatnia związana była z dynamiką dzielenia i wzajemnego przejmowania przez partnerów zadań wynikających z prowadzenia domu i opieki nad dziećmi regulowanych poziomem zaangażowania jednego z małżonków w aktywności zawodowe oraz długością jego trwania i momentem wystąpienia. Warto zwrócić uwagę na fakt, iż sam brak sprzeciwu mężczyzn wobec zawodowych działań i zaangażowania kobiet w ich odbiorze jest dużym wsparciem umożliwiających im samorealizację w innej sferze niż rodzina (Ibidem).

Znaczenie tej formy wsparcia kobiet ze strony ich partnerów można lepiej zrozumieć, gdy odwołamy się do skrajnie przeciwnego sposobu funkcjonowania w bliskiej relacji, jakim jest stosowanie przemocy. Evan Stark opracował koncepcję przemocy zwanej "zniewolenie i kontrola” (Stark, 2007), narastającą głównie w okresie dużych zmian społecznych. Służy ona zabezpieczeniu przywilejów mężczyzn i powstrzymaniu czy też opóźnianiu zmiany relacji płci w sytuacji wzrastania pozycji kobiet w życiu społecznym. Celem tej formy przemocy jest „dekonstrukcja bycia osobą” (Ibidem), a najważniejszym aspektem jest nie to, co mężczyźni robią kobietom, ale przed robieniem czego je powstrzymują. Ta forma przemocy obejmuje róż- 
ne strukturalne formy deprywacji, wykorzystywania i nakazów, które wymagają posłuszeństwa nie wprost - poprzez monopolizowanie istotnych życiowo zasobów, ograniczanie opcji i pozbawianie wsparcia potrzebnego dla tworzenia niezależnych opinii (Szymkiewicz, 2009). Zniewolenie i kontrola opisywane są głównie w kontekście dążenia do równouprawnienia, gdzie każda osoba - niezależnie od płci - ma prawo być przede wszystkim człowiekiem. Dlatego E. Stark proponuje, by „zniewolenie i kontrolę”, a także inne formy przemocy domowej traktować nie tylko jako przestępstwa kryminalne, ale również jako łamanie praw człowieka. Przeciwdziałanie „zniewoleniu i kontroli" polegałoby nie tylko na ochronie przed zdefiniowanymi aktami przemocy, ale na „zapewnieniu prawa do autonomii i wolności” (Ibidem). Stąd ujawnienie w badaniach nad partnerstwem kobiet i mężczyzn w rodzinie strategii wzajemnego wsparcia, a zwłaszcza strategii „braku sprzeciwu” staje się głównym elementem i swoistym dowodem na trwający w rodzinach partnerskich proces redefinicji ról rodzinnych (Ostrouch-Kamińska, 2011).

We współczesnych rodzinach partnerskich, często przepracowanych (rodziców), dla ich funkcjonowania, a także dla środowiska wychowawczego, jakie kreują, bardzo ważne jest wsparcie we wszystkich jego rodzajach, gdyby odwołać się do ujęcia wsparcia autorstwa Stanisława Kawuli (2002), który wyróżnił wsparcie emocjonalne, wartościujące, instrumentalne czy informacyjne. To wsparcie może być analizowane z perspektywy rozwiązań polityki rodzinnej, struktury i kultury organizacyjnej czy usług wspierających rodzinę, a więc $\mathrm{w}$ wymiarze zewnętrznym, instytucjonalnym, oraz $\mathrm{w}$ wymiarze wewnętrznym, indywidualnym, jako indywidualne strategie wsparcia organizacji życia rodzinno-zawodowego realizowane przez kobiety i mężczyzn, w centrum których znajduje się dążenie do wyższej jakości życia rodzinnego i minimalizacji (wewnętrznych) konfliktów. Może być rozważane w kontekście „obiektywnym”, związanym z poziomem i jakością realizacji zadań związanych z rolą pracownika oraz rodzica/współmałżonka, a także w kontekście „subiektywnym” - poczucia (bądź jego braku) przeciążenia rolą (por. Sęk, Cieślak, 2017).

Przepracowane rodziny nie są generalnie beneficjentami opieki i pomocy państwa oferowanych rodzinom. Nie oznacza to jednak braku potrzeby wsparcia takich rodzin. Wiążą się one głównie $z$ tworzeniem odpowiedniej atmosfery godzenia wielu ról, budową kultury współpracy kobiet i mężczyzn poprzez zmianę świadomości społecznej w kierunku większego równouprawnienia płci (rys. 1). 


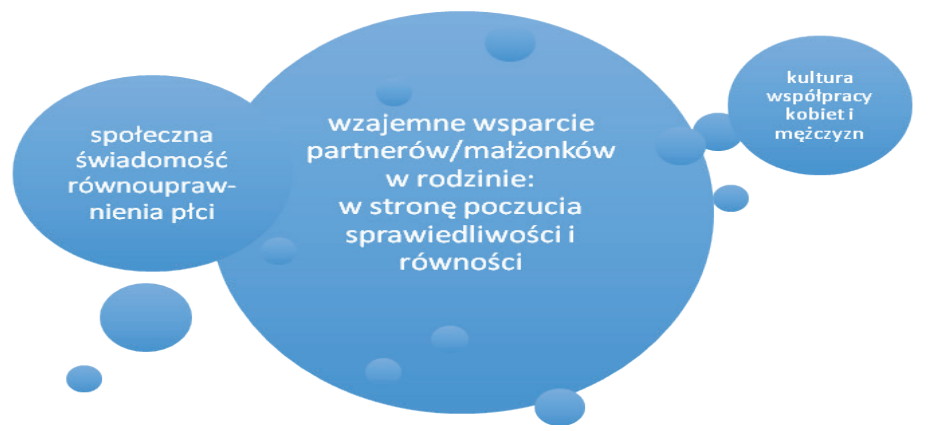

Źródło: analizy własne.

Duża grupa potrzeb wsparcia współczesnych rodzin zaangażowanych w profesjonalny rozwój rodziców wynika z istniejących w świadomości społecznej wzorców ról związanych z płcią. Ich dychotomiczne ujmowanie, zbyt wolna w stosunku do przemian sposobów życia oraz wymogów rynku pracy redefinicja, a także negatywne wartościowanie zachowań niezgodnych z kulturowymi definicjami, staje się źródłem wielu dylematów i wewnętrznych konfliktów osób wykraczających poza rodzajowy schemat. Potrzeby zmiany na poziomie społecznych i kulturowych definicji wzorców ról rodzajowych w kierunku ich większej otwartości wiążą się z potrzebą poszerzania świadomości pracodawców oraz zmian w obrębie kultury organizacji, rynku i organizacji pracy, a także z działaniami państwa w zakresie ustanowienia przepisów ułatwiających funkcjonowanie przepracowanej rodzinie oraz wspierania rozwoju sektora usług skierowanych w jej stronę, np. dobrej jakości żłobków i przedszkoli, czy pomocy w opiece nad osobami zależnymi starszymi, chorymi i niepełnosprawnymi. Wsparcie realizowane w tej sferze potrzeb wiązałoby się z działaniami o charakterze edukacyjnym, których celem byłoby: poznanie specyfiki procesu godzenia równolegle wielu ról nie tylko przez kobiety, ale również przez mężczyzn; demitologizacja konsekwencji funkcjonowania w przepracowanej rodzinie - również w kontekście rozwoju dzieci, przede wszystkim zaś zmiana świadomości społecznej w kierunku akceptacji większego partnerstwa kobiet i mężczyzn zarówno na rynku pracy (potrzeby odczuwanej głównie przez kobiety), jak i w rodzinie (głównie ze względu na mężczyzn-ojców). Realizację tych celów umożliwiłaby jedynie edukacja krytyczna, nastawiona na realizację niezbywalnej jej roli, jaką jest według Zbigniewa Kwiecińskiego „pomoc w kształtowaniu 
człowieka na miarę złożonych wyzwań współczesności" (Kwieciński, 2002, s. 114), skierowana na zmianę świadomości społecznej oraz, jak pisze Bogusław Śliwerski, na zmianę kultury pedagogicznej i politycznej z totalitarnej, np. patriarchalnej, na „podmiotową, demokratyczną, partycypacyjną czy uspołecznioną" (Śliwerski, 2003, s. 393).

\section{Krytyczna edukacja (nieformalna) w rodzinie: w stronę małżeńskiego „ja”}

Nieodzownym elementem życia współczesnego człowieka umożliwiającym adaptację do zmiennych warunków życia jest nieustanne negocjowanie codzienności, analiza okoliczności własnego życia i uczenie się w toku własnych doświadczeń w codziennych interakcjach (Illeris, 2006). Badania pokazują (Mikołajczyk-Lerman, 2006; Ostrouch-Kamińska, 2011; Nowak-Dziemianowicz, 2016), że istnienie współczesnych rodzin, zwłaszcza tych próbujących na co dzień budować własne relacje w odmienny od swoich rodzin pochodzenia sposób, jest związane z procesem nieustannego negocjowania kształtu rodzinnej codzienności. Można go zaobserwować w codzienności partnerskiej rodziny, którą tworzą małżonkowie realizujący równolegle swoje profesjonalne i domowe role, a zwłaszcza gdy robią to $z$ równoległym dużym zaangażowaniem w obie te sfery życia. Przemiana sytuacji i roli kobiet we współczesnym społeczeństwie, związana ze wzrostem poziomu ich wykształcenia i chęci samorozwoju, a w konsekwencji także poziomu zaangażowania zawodowego, wymaga reorganizacji życia rodzinnego, zwłaszcza w kontekście opieki nad dziećmi, oraz bardziej elastycznego, egalitarnego rodzicielstwa (Ostrouch-Kamińska, 2013).

Jak wspomniałam wcześniej, w „przepracowanych rodzinach” zmienia się styl życia, wymuszając na małżonkach modyfikację tradycyjnego podziału obowiązków i zadań w rodzinie. Dzięki analizie funkcjonowania takich rodzin, dużo więcej dziś wiemy np. o wpływie pracy zawodowej na rozwój i wychowanie dzieci - obok podkreślania głównie negatywnych konsekwencji zawodowego zaangażowania kobiet na rozwój dziecka, zwłaszcza w pierwszych latach życia, mających swe źródła w klasycznej teorii przywiązania (Bowlby, 2007), coraz częściej zwraca się uwagę także na jego pozytywne konsekwencje zarówno dla rozwoju dziecka, jak i funkcjonowania matek w roli rodzinnej oraz profesjonalnej (Holcomb, 1998; Barnett, Rivers, 1996). Dużo więcej wiemy też np. na temat znaczenia obecności i aktywnego za- 
angażowania mężczyzn w życie rodziny, a przede wszystkich w życie dzieci (Marsiglio, Pleck, 2005; Kubicki, 2009).

Natomiast dużo mniej wiadomo na temat samego procesu modyfikacji tego tradycyjnego podziału obowiązków i zadań w rodzinie, redefiniowania ról i wartości oraz konstruowania nowych. Dokonują się one bowiem w sposób nieuchwytny i często nieświadomiony; w procesie wzajemnego uczenia się w relacjach w rodzinnej codzienności, w toku własnych doświadczeń (Malewski, 2000). Zdaniem Jeana C. Kaufmanna (2004), rozwijającego socjologię pary, współcześnie para (małżonków) i relacja pomiędzy nimi zyskuje na znaczeniu w biografii człowieka. Autor podkreśla, iż zawarcie małżeństwa to „dramatyczny akt, w którym spotykają się i realizują dwie obce osoby” (Kaufmann, 2004, s. 195). Owy dramatyzm polega na zachwianiu dotychczasowych odniesień na temat tożsamości i konieczności skonstruowania zupełnie nowej wersji rzeczywistości dla dwóch osób, utworzenia od wewnątrz „małżeńskiego ja”, a więc przebudowania siebie poprzez zderzenie dwóch odmiennych „spuścizn przyzwyczajeń" (Ibidem). Trwałe i nieformalne interakcje w małżeństwie prowadzą, zdaniem autora, do trzeciego - obok socjalizacji pierwotnej i wtórnej - typu socjalizacji, który odznacza się tworzeniem części tożsamości w zbiorowej postaci. Małżeństwo okazuje się być przestrzenią trzech sfer wpływów dotyczących tożsamości: jej, jego i wspólnej - „małżeńskiego ja” (Ibidem, s. 194-195).

Podobnie o małżeńskiej relacji jako przestrzeni konstruowania nowego „ja” piszą Peter Berger i Hansfried Kellner (1964), lokując ten proces w biograficznym doświadczeniu. Według autorów, rodziny generują swoje intymne, indywidualne znaczenia, które zwykle nie ujawniają się poza rodziną, a które budowane są przez członków rodziny w oparciu o wspólną historię, perspektywę oraz interpretację wydarzeń. W obrębie każdego mikroświatu, jakim jest również rodzina, funkcjonują określone założenia i konstrukcje znaczeń, które kierują doświadczeniami i je formują. Sfera rodziny obejmuje poczucie dzielenia zarówno historii, jak i przyszłości, a także poczucie posiadania „biografii”. Zawarcie związku małżeńskiego oznacza zatem proces „fuzji biografii”, w którym nie tylko zaczyna się dzielić wspólne doświadczenia, ale również sposoby ich konstruowania, rozumienia i wyjaśniania (Klein, White, 1996). Rozumienie jest tu szczególną formą doświadczenia, w której jak pisał Alfred Schütz (2008, s. 9) „myślenie zdroworozsądkowe zapoznaje się ze światem społeczno-kulturowym", będąc rezultatem procesu uczenia się.

Uczenie się traktuję tu jako proces, a nie jego rezultat, jako zachowanie aktywne i społeczne, w którym „tworzą się znaczenia w celu lepszego ro- 
zumienia rzeczywistości” (Bron, 2006, s. 9). W przypadku uczenia się partnerstwa w rodzinie, gdy kobieta i mężczyzna rozpoczynają wspomnianą małżeńską, biograficzną fuzję, wnoszą oni do wspólnego związku wykształcenie, rozbudzoną ciekawość poznawczą, aksjologiczny kapitał w postaci etosu pracy i osobistego rozwoju oraz przekonanie o sile własnego sprawstwa, ale także ugruntowaną w trajektorii życia określoną koncepcję bycia kobietą i mężczyzną w relacji oraz w roli (Ostrouch-Kamińska, 2011). W codziennych interakcjach modyfikują je, uczestnicząc w procesach, podczas których wspólnie „konstruują doświadczenie sytuacyjne oraz przekształcają je w wiedzę, umiejętności, postawy, przekonania, wartości, emocje, sensy i znaczenia oraz integrują je w obrębie własnej biografii" (Gutowska, 2013; por. Malewski, 2010). Ważnym elementem konstytuującym te procesy jest równość rozumiana nie tylko jako równoważność podmiotów, praw partnerów i ich potrzeb, ale przede wszystkim jako wzajemne wspieranie się: "gdy współmałżonkowie hojnie dają i bez skrępowania przyjmują" (Myers, 2004, s. 218), wspólne podejmowanie decyzji oraz wspólne zaangażowanie, z którym wiąże się gotowość do zwierzeń, wzajemne ujawnianie siebie i intymnych szczegółów dotyczących własnego życia, własnych emocji, marzeń, pragnień i zmartwień jako podstawy budowanej bliskości. Swoista równość małżonków jest tu rozumiana jako bycie równym rangą, na równi z partnerem/-ką, stanie na równej pozycji; to negocjacje prowadzone z tego samego poziomu (np. władzy) w relacji; to płynna regulacja oraz dzielenie ról rodzinnych i związanych z nimi pozycji. Relacje te są więc symetryczne, ale nie w sensie równej miary estymy. Symetryczność w tym wypadku oznacza, jak mówi Axel Honneth (Honneth, 2005; por. Modrzyk, 2010), szansę bycia docenionym za własne zdolności i osiągnięcia, bez doświadczenia pogardy. Uznanie ludzkiej godności staje się więc główną zasadą regulującą życie małżonków.

\section{Refleksje końcowe}

Odwołując się do andragogicznych teorii akcentujących procesualny wymiar uczenia się, osadzonego w szerokim społeczno-kulturowym kontekście, uczenie się partnerstwa w rodzinie w relacji małżeńskiej jest związane z codziennym doświadczeniem oraz biograficznym kształtowaniem własnej tożsamości w procesie (samo)refleksji. Refleksja i samorefleksja stają się tu podstawą biograficznego uczenia się, w którym akcentuje się, jak pisze Peter Alheit, „uczenie się jako (trans)formację struktur doświadczenia, wiedzy 
i działania w kontekście wszystkich aspektów życia ludzi i otaczającej ich rzeczywistości" (Alheit, 2002, s. 65). Wiedza biograficzna, czyli taka, która została przeżyta i uświadomiona, staje się tu wiedzą transformatywną, przekształcającą jednostki w zależności od zmieniającej się sytuacji życiowej (por. Solarczyk-Szwec, 2015).

Zatem uczenie się partnerstwa w rodzinie będzie związane $\mathrm{z}$ nieustannym procesem konstruowania zajmowanych pozycji $\mathrm{w}$ relacji, a nie ich przypis(yw)ania; z procesem negocjacji kształtu własnych tożsamości (rodzajowych) małżonków oraz konstruowania intymnych relacji wewnątrzrodzinnych i „małżeńskiego ja” przez dwa równoprawne podmioty poprzez refleksyjne porządkowanie biografii. Proces ten stwarza współmałżonkom przestrzeń do dokonywania samodzielnych wyborów i osobistego rozwoju, jednocześnie wymagając od nich wzajemnego wsparcia, umiejętności nieustannego poruszania się wśród sprzeczności oraz odpowiedzialnego korzystania z praw i nowych warunków życia rodzinnego, często odmiennych od tych doświadczanych $\mathrm{w}$ rodzinie pochodzenia. Wiąże się on $\mathrm{z}$ koniecznością przebudowy etyki życia rodzinno-małżeńskiego w kierunku eliminowania nierówności kobiet i mężczyzn oraz budowania równowagi w relacji (Struening, 2002), a także z koniecznością redefinicji i poszerzania koncepcji ról płciowych nie tylko w rodzinie, ale również w społeczeństwie i w kulturze jako podstawy zewnętrznego, instytucjonalnego wsparcia okazywanego współczesnej rodzinie.

\section{Bibliografia}

Alheit P. (2002), „Podwójne oblicze” catożyciowego uczenia się: dwie analityczne perspektywy cichej rewolucji, „Teraźniejszość - Człowiek - Edukacja. Kwartalnik myśli społeczno-pedagogicznej", nr 2.

Balswick J. (1995), The Dual-Earner Marriage: The Elaborate Act, Fleming H. Revell, Grand Rapids.

Barnett R.C., Rivers C. (1996), She Works. He Works. How Two-Income Families are Happier, Healthier, and Better - Off, Harper Collins, San Francisco.

Bauman Z. (2007), Płynna nowoczesność, Wydawnictwo Literackie, Kraków.

Berger P., Kellner H. (1964), Marriage and the construction of reality, „Diogenes”, nr 46. Bowlby J. (2007), Przywiqzanie, Wydawnictwo Naukowe PWN, Warszawa.

Bron A. (2006), Rozumienie uczenia się w teoriach andragogicznych, „Teraźniejszość Człowiek - Edukacja. Kwartalnik myśli społeczno-pedagogicznej”, nr 4.

Dąbrowska Z. (2002), Przegląd polskich badań familiologicznych z lat dziewięćdziesiqutych, część I-III, „Małżeństwo i Rodzina”, nr 1-3. 
Dench G. (1998), Pocałunek królewny. Problem mężczyzn, Wydawnictwo IFiS PAN, Warszawa.

Domański H., Firkowska-Mankiewicz A., Janicka K., Titkow A. (1993), Społeczeństwo bez regut, [w:] A. Rychard, M. Federowicz (red.) Społeczeństwo w transformacji. Ekspertyzy i studia, Wydawnictwo IFiS PAN, Warszawa.

Duch-Krzysztoszek D. (2007), Kto rzq̨dzi w rodzinie. Socjologiczna analiza relacji $w$ małżenstwie, Wydawnictwo IFiS PAN, Warszawa.

Giddens A. (1998), Socjologia. Zwięzłe, lecz krytyczne wprowadzenie, Zysk i S-ka Wydawnictwo, Poznań.

Giddens A. (1999), Trzecia droga. Odnowa Socjaldemokracji, Książka i Wiedza, Warszawa.

Giza-Poleszczuk A. (2005), Rodzina a system społeczny. Reprodukcja i kooperacja $w$ perspektywie interdyscyplinarnej, Wydawnictwo UW, Warszawa.

Gutowska A. (2013), Uczenie się w sytuacji przyjaźni w perspektywie andragogicznej, „Rocznik Andragogiczny”.

Holcomb B. (1998), Not guilty: The good news about working mothers, Scribner, New York.

Honneth A. (2005), Redystrybucja jako uznanie. Odpowiedź dla Nancy Fraser, [w:] N. Fraser, A. Honneth, Redystrybucja czy uznanie? Debata polityczno-filozoficzna, Wydawnictwo Naukowe DSW, Wrocław.

Illeris K. (2006), Trzy wymiary uczenia się. Poznawcze, emocjonalne i społeczne ramy uczenia się, Wydawnictwo DSW, Wrocław.

Kaufmann J. C. (2004), Ego: socjologia jednostki. Inna wizja człowieka i konstrukcji podmiotu, Oficyna Naukowa, Warszawa.

Kawula S. (2002), Pomocniczość i wsparcie. Kategorie pedagogiki społecznej, Oficyna Wydawnicza Kastalia, Olsztyn.

Klein D. M., White J. M. (1996) Family Theories. An Introduction, SAGE Publications, Thousand Oaks, London, New Delhi.

Kubicki P. (2009), Przemiany ojcostwa we wspótczesnej Polsce, [w:] M. Sikorska (red.) Być rodzicem we wspótczesnej Polsce. Nowe wzory w konfrontacji z rzeczywistością, Wydawnictwa UW, Warszawa.

Kwieciński Z. (2002), Nieuniknione? Funkcje alfabetyzacji $w$ dorosłości, Wydawnictwo UMK, Toruń-Olsztyn.

Malewski M. (2000), Modele pracy edukacyjnej z ludźmi dorosłymi, „Teraźniejszość Człowiek - Edukacja. Kwartalnik myśli społeczno-pedagogicznej”, nr 1.

Malewski M. (2010), Od nauczania do uczenia się. O paradygmatycznej zmianie $w$ andragogice, Wydawnictwo Naukowe DSW, Wrocław.

Mandal E. (2008), Miłość, władza i manipulacja w bliskich związkach, Wydawnictwo Naukowe PWN, Warszawa.

Marsiglio W., Pleck J. H. (2005), Fatherhood and Masculinities, [w:] M. S. Kimmel, J. Henra, R. W. Connell (red.) Handbook of Studies on Men and Masculinities, Sage Publications, Thousand Oaks-London-New Delhi. 
Mikołajczyk-Lerman G. (2006), Mężowie i żony. Realizacja ról małżeńskich $w$ rodzinach wielkomiejskich, Wydawnictwo UŁ, Łódź.

Modrzyk A. (2010), Ku wspólnocie posttradycyjnej. Axel Honneth jako krytyk komunitariańskiej filozofii politycznej, „Praktyka Teoretyczna”, nr 1.

Myers D. G. (2004), Bliskie związki a jakość życia, [w:] J. Czapiński (red.) Psychologia pozytywna. Nauka o szczęściu, zdrowiu, sile i cnotach człowieka, Wydawnictwo Naukowe PWN, Warszawa.

Nowak-Dziemianowicz M. (2002), Doświadczenia rodzinne w narracjach. Interpretacje sensów i znaczeń, Wydawnictwo UWr, Wrocław.

Nowak-Dziemianowicz M. (2016), Walka o uznanie w narracjach. Jednostka i wspólnota $w$ procesie poszukiwania tożsamości, Wydawnictwo Naukowe DSW, Wrocław.

Ostrouch-Kamińska J. (2011), Rodzina partnerska jako relacja współzależnych podmiotów. Studium socjopedagogiczne narracji rodziców przeciążonych rolami, Oficyna Wydawnicza „Impuls”, Kraków.

Ostrouch-Kamińska J. (2013), Egalitarne rodzicielstwo, „Szkice Humanistyczne”, nr 1, tom XIII, vol. 31.

Pankowska D. (2005), Wychowanie a role płciowe, GWP, Gdańsk.

Rostowska T. (2008), Małżeństwo, rodzina, praca a jakość życia, Oficyna Wydawnicza „Impuls”, Kraków.

Rostowska T. (2009), Aktywność zawodowa małżonków a jakość ich życia, [w:] T. Rostowska (red.), Psychologia rodziny. Małżenstwo i rodzina wobec współczesnych wyzwań, Difin SA, Warszawa.

Rostowski J. (1987), Zarys psychologii małżeństwa: psychologiczne uwarunkowania dobranego związu małżeńskiego, PWN, Warszawa.

Schütz A. (2008), Tworzenie pojęć i teorii w naukach społecznych, [w:] A. Schütz, O wielości światów. Szkice z socjologii fenomenologicznej, Zakład Wydawniczy „NOMOS”, Kraków.

Sęk H., Cieślak R. (2017), Wsparcie społeczne - sposoby definiowania, rodzaje i źródła wsparcia, wybrane koncepcje teoretyczne, [w:] H. Sęk, R. Cieślak (red.), Wsparcie społeczne, stres i zdrowie, Wydawnictwo Naukowe PWN, Warszawa.

Slany K. (2002), Alternatywne formy życia małżeńsko-rodzinnego w ponowoczesnym świecie, Zakład Wydawniczy „NOMOS”, Kraków.

Smolińska-Theiss B. (2014), Dzieciństwo jako status społeczny: edukacyjne przywileje dzieci klasy średniej, Wydawnictwo APS, Warszawa.

Solarczyk-Szwec H. (2015), Cztery ćwiartki biograficznego uczenia się, „Rocznik Andragogiczny".

Stark E. (2007), Coercive Control. How Men Entrap Women in Personal Life, Oxford University Press, New York.

Struening K. (2002), New Family Values. Liberty, Equality, Diversity, Rowman \& Littlefield Publishers, Lonham, Boulder, New York, Oxford.

Szlendak T. (2010), Socjologia rodziny. Ewolucja, historia, zróżnicowanie, Wydawnictwo Naukowe PWN, Warszawa. 
Sztompka P. (2000), Trauma wielkiej zmiany. Spoteczne koszty transformacji, ISP PAN, Warszawa.

Sztompka P. (2004), Socjologia. Analiza społeczeństwa, Wydawnictwo Znak, Kraków. Szymkiewicz B. (2009), Zniewolenie i kontrola. Przemoc domowa jako łamanie praw człowieka, „Niebieska Linia”, nr 5 (64).

Śliwerski B. (2003), Pedagogika antyautorytarna, [w:] Z. Kwieciński, B. Śliwerski (red.), Pedagogika, Tom 1, Wydawnictwo Naukowe PWN, Warszawa.

Tyszka Z. (2002), Rodzina we wspótczesnym świecie. Poznań, Wydawnictwo Naukowe UAM.

VanEvery J. (1999), From modern nuclear family households to postmodern diversity? The sociological construction of 'families', [w:] G. Jagger, C. Wright (red.), Changing Family Values: Feminist Perspectives, Routledge, London and New York. 